DOI 10.15290/cnisk.2018.01.04.06

DR HAB. PIOTR CHOMIK, PROF. UWB

orcid.org/0000-0003-1329-7352

Uniwersytet w Białymstoku

\title{
O bóstwach żeńskich w mitologii germańskiej i hinduizmie
}

\section{Streszczenie}

Przedmiotem niniejszego tekstu są miejsca i funkcje bóstw kobiecych w panteonach bogów germańskich i hinduistycznych. W mitologii germańskiej najważniejsze były podziały na siły symboliczne męskie i żeńskie, a nie modelowy podział bogów i ludzi na sfery władzy, wojny i dobrobytu. Wśród bóstw żeńskich mitologii germańskiej należy wymienić: Frigg jako królowa Asów i Asynii, Sagę, Eir, Gefjon, Fullę, Sif, Lofn, Vor, Vanr, Syn, Hlin, Snotrę i Gnę oraz należąe do Wanów Nerthus i Freję. Wybuch wojny pomiędzy Asami a Wanami powoduje pojawienie się tajemniczej kobiety Gullveig. Spośród grup bogiń skandynawskich wyraźnie odrębne od męskiej części panteonu były Disy, boginie zwiazane ze sfera płodności i śmierci.

Tradycja Wielkiej Bogini jest w hinduizmie nie mniej ważna niż tradycje Wisznu i Śiwy. Niezliczone bóstwa żeńskie w tradycjach lokalnych sa zazwyczaj uznawane przez Hindusów za personifikacje czy aspekty jedynej Wielkiej Bogini, której kult sięga najprawdopodobniej czasów prehistorycznych. W hinduizmie wszystkie boginie sa tylko jakimś aspektem jednej Bogini, działającej w różny sposób, zależnie od konkretnej sytuacji. Najważniejsze $z$ nich to boginie Durga i Kali. W hinduizmie popularne sa też zwiazki par Bogów, które maja być przykładami idealnych związków pomiędzy kobieta a mężczyzną. Należą do nich zwiąki Ramy i Sity, Kriszny i Radhy, Siwy i Parwati czy Wisznu i Lakszmi.

Słowa kluczowe: religia, hinduizm, mitologia germańska, kobieta, bóstwa 


\title{
ABOUT FEMALE DEITIES IN GERMANIC MYTHOLOGY AND HINDUISM
}

\begin{abstract}
The purpose of this work is to present the hierarchy and the functions of female deities in the pantheons of Germanic and Hindu gods. In German mythology, the most important was the division into male and female symbolic forces, not the model division of gods and people into spheres of power, war and prosperity. Among the female deities of Germanic mythology, the following goddesses are worth mentioning: Frigg as Queen of Ases, Saga, Eir, Gefjon, Fulla, Sif, Lofn, Vor, Vanr, Son, Hlin, Snotra, Gna, Nerthus and Freya. The outbreak of the war between the Aces and the Vanir results in the appearance of a mysterious woman Gullveig. Disas - goddesses of fertility and death - make a separate female group in Scandinavian mythology.

The tradition of the Mother Goddess in Hinduism is just as important as the traditions of Vishnu and Shiva. Innumerable female deities in the local traditions are usually regarded by Hindu people as personifications of the one and only Mother Goddess, the worship of whom dates back to prehistoric times. In Hinduism, all of the goddesses personify aspects of the one true God who, depending on a specific situation, acts in a different manner. The most important goddesses are Durga and Kali. It is also worth mentioning that relationships among the couples of Gods are to be the example of an ideal relationship between a woman and a man. These include relationships of Rama and Sita, Kriszna and Radha, Shiva and Parvati or Vishnu and Lakshmi.
\end{abstract}

Keywords: religion, Hinduism, Germanic mythology, woman, deities

$*$

Im dalej cofamy się w czasie, tym bardziej kultura i religia sa ze soba zespolone. Obyczajowość, prawo, handel, sztuka, wiedza, a przede wszystkim codzienność, zwykłe ludzkie życie występuja w świetle pojęć religijnych. Dlatego zrozumiałe jest, że w religiach pierwotnych oraz przedchrześcijańskich czy niechrześcijańskich można było obserwować różne formy rozwoju wierzeń i panteonów bóstw, w których jakąś rolę odgrywały praktyki zwiazane $z$ płcia i jej tradycyjnymi rolami.

Przedmiotem niniejszego tekstu będa miejsca i funkcje bóstw kobiecych w panteonach bogów germańskich (skandynawskich) i hinduistycznych. Zwracam przy tym uwagę, że określenie „mitologia ger- 
mańska” czy „religia germańska” jest nieprecyzyjne. Stanowi o tym przymiotnik "germański”, używany zbyt szeroko. W gruncie rzeczy dość wasska podstawa źródłowa odnosi się do Skandynawii, zbywając milczeniem wiele zasadniczych kwestii odnoszacych się do Germanów kontynentalnych, chociaż kulty germańskie powstały wcześniej. Obecnie najważniejszym źródłem sa poematy o bogach ze Starszej Eddy spisane w XII w. oraz dzieło Snorriego Sturlusona o sztuce poetyckiej $z$ około 1220 r. Korzystamy również ze źródeł arabskich podróżników oraz relacji chrześcijan. Dzięki archeologii najwięcej wiemy o obrzędach pogrzebowych, pomnikach, ofiarach i piśmie runicznym. Źródłami, z których czerpiemy swoją wiedzę na temat początku świata, sa trzynastowieczne poematy: Völspa (Wieszczba Wölwy), Grimnismál (Pieśń Grimnira) oraz Vafthrúdnismál (Pieśń o Wafthrundnirze), wszystkie rozwinięte i przełożone w Eddzie młodszej Snorriego Sturlusona ${ }^{1}$.

„Przegląd bóstw” kobiecych w religii germańskiej (skandynawskiej) należy zaczać od uwagi Leszka Słupeckiego, który stwierdził, że $\mathrm{w}$ mitologii skandynawskiej - w przeciwieństwie do innych religii indoeuropejskich - najważniejsze były podziały na siły symboliczne męskie i żeńskie, a nie modelowy podział bogów i ludzi na sfery władzy, wojny i dobrobytu ${ }^{2}$.

W mitologii skandynawskiej dwie najważniejsze grupy - a ściślej mówiąc, rody - bóstw to Asowie i Wanowie. Domena Asów były sprawy władzy i wojny, gwarantowali poszanowanie prawa, mieli pewne cechy bóstw niebiańskich i zdecydowanie męskie oblicze. Wanowie panowali nad sferami dobrobytu, płodności i pewnymi formami magii, gwarantowali pokój, mieli wyraźne cechy bóstw świata podziemnego i byli związani symbolicznie $z$ mocami żeńskimi. Przypisywano im też szczególną biegłość w sprawowaniu kultu religijnego ${ }^{3}$. Nie oznacza to jednak, że wśród Asów nie pojawiły się bóstwa żeńskie. Snorri Sturluson w Eddzie młodszej wylicza: Frigg jako królową Asów i Asynii oraz Sagę, Eir, Gefjon, Fullę, Sif, Lofn, Vor, Vanr, Syn, Hlin, Snotrę i Gnę. Wraz z nimi wspomina należącą do Wanów Freję. Jak zauważa Słupecki, wszystkie kobiety Asów stawały się Asyniami, również te pochodzące $z$ innych rodów ${ }^{4}$.

\footnotetext{
1 Szerzej na temat źródeł religii germańskiej zob. S. Piekarczyk, Mitologia germańska, Warszawa 1979, s. 17-27.

2 L.P. Słupecki, Mitologia skandynawska w epoce Wikingów, Kraków 2014, s. 69.

3 Ibidem, s. 75.

4 Ibidem, s. 76.
} 
Do Wanów źródła zaliczają Njorda, jego siostrę wymienianą w źródłach bez imienia oraz ich dzieci - Freja i Freję. Były to bóstwa będące zakładnikami Asów w wyniku wojny pomiędzy grupami bogów. Można do nich dodać Gullveig oraz Inga, zapewne tożsamych z Freją i Frejem. Wśród Wanów do czasu ich pojednania $z$ Asami dozwolone miały być małżeństwa pomiędzy bliskimi krewnymi, w tym także pomiędzy rodzeństwem. W Eddzie młodszej mówi się o tym, że Njord, mieszkając jeszcze w siedzibie Wanów Wanaheimie, miał za żonę własną siostrę, z która spłodził wspomnianych Freja i Freję. Leszek Słupecki przypomina, że również Freję zastano w łóżku $z$ własnym bratem, co wypominał jej Loki. Wanowie musieli porzucić zwyczaje tego rodzaju, gdy znaleźli się wśród Asów ${ }^{5}$. Powyższa charakterystyka wskazuje, że spójność grupy oparta była na kulcie płodności (drugim filarem było skupienie wokół spraw rolniczych).

Mit o wojnie pomiędzy Asami i Wanami podkreśla różnice zachodzące pomiędzy tymi boskimi grupami. Po zakończeniu wojny i pojednaniu uzupełniają się one wzajemnie. Wojna Asów z Wanami, co zauważył Georges Dumézil, ma charakter sakralny, a opowieść o niej służy pokazaniu różnych funkcji dwóch grup bogów w formie mitu o konflikcie pomiędzy nimi. Ostatecznie wojna prowadzi do współpracy obu zwaśnionych wcześniej grup boskich ${ }^{6}$.

Wybuch wojny pomiędzy Asami a Wanami powoduje pojawienie się Gullveig ${ }^{7}$, tajemniczej kobiety, wspominanej wyłącznie w Eddzie poetyckiej, gdzie zapisano, że w zwiazku z poczatkiem pierwszej wojny $w$ świecie, Asowie po trzykroć nabili Gullveig na włócznie i spalili, ta jednak odradzała się za każdym razem, wiecznie żywa. Ulubionym przedmiotem przypuszczeń w badaniach mitu Gullveig jest rozpasanie seksualne powiazane $z$ uprawianiem seidr (szamanizmu) lub podejrzenia o incest. Niekiedy badacze utożsamiają Gullveig z Freja, o czym świadczyć maja wspólne cechy tych postaci: zamiłowanie do seksu, podejrzenie

\footnotetext{
Ibidem, s. 78-79.

6 G. Dumézil, Bogowie Germanów. Szkice o kształtowaniu się religii skandynawskiej, przeł. A. Gronowska, Warszawa 2006, s. 14-19; L.P. Słupecki, op. cit., s. 80.

7 Imię Gullveig oznacza „złoty napój” i odnosi się do miodu. W świecie Asów w okresie pokoju był to napój całkowicie nieznany. Mieli oni za to złote tablice do gry, które w wyniku rozpoczęcia wojny utracili. Teraz uzyskali złoty napój, trunek wprawiający świat w ruch, tworzący zmiany, przynoszący wojny i wiodący świat do nieuchronnego końca. Napój ten przynosi Asom kobieta, która w ten sposób wprowadza do ich świata zamęt (L.P. Słupecki, op. cit., s. 82).
} 
o incest, a także znajomość sztuki seidr. Po pojednaniu Asów z Wanami Freja pojawiła się wśród nich i wprowadziła w tajniki seidr. Gullveig, gdy praktykowała seidr, była określana imieniem Heidr. Słowo to było typowym imieniem wieszczek. Czary dawały Gullveig zdolność prorokowania, dokonywały się wewnątrz domostw, odbywały się, gdy była ona $\mathrm{w}$ transie. Wszystkie te elementy obecne sa w znanych opisach praktyk seidr zawartych w sagach. Pojawienie się Gullveig oznacza początek nieuchronnego i niespokojnego biegu dziejów ${ }^{8}$.

Pierwszym bóstwem, które możemy zaliczyć do grupy Wanów, jest opisana jeszcze w starożytności bogini Nerthus. Jako Matkę ziemię miało ją czcić siedem nadmorskich plemion germańskich zamieszkujacych od Fryzji przez Szlezwik i Jutlandię aż po ziemie Warnów. Według Tacyta nadmorskie plemiona wierzyły w przychylność Nerthus dla ludzi objawiająca się tym, że raz do roku pozwalała się obwozić wśród oddajacych jej cześć ludów, jadąc wozem zaprzężonym w krowy. Jej wóz był pojazdem szczególnym, osłoniętym i uświęconym. Przejazd miał charakter sakralny i rytualny, i był nadzorowany przez kapłanów, $z$ czym wiązały się wyobrażenia o symbolicznych, rytualnych godach bogini z jej małżonkiem. Towarzyszyły temu rytualne, symboliczne czynności oczyszczenia polegające na obmywaniu jej posagu. Czas objazdu był okresem radości, zaprzestawano wówczas walk i wojen, nie noszono broni ani przedmiotów z żelaza. Po zakończonym objeździe boginię odwożono do sanktuarium. Tam obmywano wóz, zasłony i samą boginię (jej posag lub kapłankę). Przy tych czynnościach pomagali niewolnicy, którzy prawdopodobnie byli później topieni w jeziorze, w ofierze dla bogini. Bóstwo okazywało więc na zakończenie misterium swoją druga, bardziej demoniczną naturę?.

Pozostaje jeszcze do wyjaśnienia problem zwiąku kultu starożytnej Nerthus ze średniowiecznymi Wanami. Męski partner Nerthus nie został bezpośrednio potwierdzony w żadnym źródle. Jednak męskim odpowiednikiem imienia Nerthus jest Njord, czyli bóstwo męskie w Skandynawii związane z woda, którego imię oznaczało „siłę stwórcza”. Zatem domniemany starożytny poprzednik Njorda mógł być partnerem Nerthus. Można więc przyjąć, iż w starożytności Njord był bratem i part-

8 Edda poetycka, ze staroislandzkiego przeł. i oprac. A. Załuska-Strömberg, Wrocław 1986, s. 8; L.P. Słupecki, op. cit., s. 81-83.

9 W. Niemczyk, Historia religii, Warszawa 1986, s. 454; L.P. Słupecki, op. cit., s. 160-161, 165. 
nerem Nerthus, a w średniowieczu Nerthus stała się partnerką Njorda, jego żoną, matką Freja i Frei, którzy później - patrząc z religioznawczego punktu widzenia - stali się odnowieniem tej pary. Oczywiście po przeniesieniu się do świata Asów Njord musiał porzucić Nerthus jako żonę ${ }^{10}$.

Przejdę teraz do omówienia wybranych postaci pozostałych bogiń germańskich (skandynawskich). Jak już można było zauważyć, żeńskie bóstwa pojawiają się w mitologii skandynawskiej pod różnymi nazwami i w różnych rolach. Bardzo często są to role wyraźnie określone, odrębne od męskiej części panteonu. Występuja tu grupy bogiń, Disy, Norny, Fylgie czy Walkirie, ale też boginie osobowe, pojedyncze, takie jak Hlodyna, Idunn czy wspominana już wcześniej Freja.

Imię Freja oznacza „Pani” i mógł to być wcześniej przydomek bogini Frigg. Przemawia za tym fakt, że obie boginie miały tego samego męża. Freja zaliczana była do Wanów, o czym świadczą zachowane w źródłach określenia jej postaci: bogini, oblubienica. Ponadto w źródłach odnotowano, że Freja była najczcigodniejsza z bogiń i miała swą siedzibę w niebiosach, a gdy ruszała do walki, połowa poległych należała do niej, a połowa do Odyna. Była zatem żeńskim odpowiednikiem Odyna, a jej siedziba nieprzypadkowo nazywała się Folkvang, czyli „pole bitwy”. Na polach bitewnych Freja nie pojawiała się jednak osobiście. Jedynie za pomocą Walkirii Gondul (posyłajac ją lub wcielając się w nia) spowodowała nigdy niekończąca się bitwę pomiędzy Hedinem a Hognim. Widzimy tu wyraźnie zarysowany wątek eschatologiczny i związki Frei ze światem śmierci. Wspomniana bitwa codziennie kończy się śmiercią większości jej uczestników. Wieczorem wojownicy sa ożywiani przez Walkirie i każdego ranka walka rozpoczyna się od nowa po to, by trwać aż do końca świata. $Z$ punktu widzenia niniejszego tekstu ważne jest to, że do Folkvangu Frei oprócz wojowników trafiały też kobiety, chociaż istnieje tylko jedno świadectwo o tym mówiące, a dotyczace Thorgerdy, córki Egila Skalla-Grimssona, bohatera jednej $z$ sag. Thorgerda po śmierci chciała trafić wraz z ojcem do zaświatów Frei.

10 W. Niemczyk, op. cit., s. 455; L.P. Słupecki, op. cit., s. 165-167. Drugą żoną Njorda była Olbrzymka Skadi. Jako zadośćuczynienie za śmierć swojego ojca mogła ona wybrać sobie męża spośród bogów, patrząc tylko na ich nogi. Widząc piękne nogi, Skadi była przekonana, że należą one do Baldra, który był jej wymarzonym kandydatem. Tymczasem były to nogi Njorda. Małżeństwo to szybko się rozpadło, gdyż Skadi nie chciała mieszkać u męża nad morzem, a Njord u żony w górach (L.P. Słupecki, op. cit., s. 167). 
Zwiazki $z$ wojna i zaświatami to nie jedyne elementy natury Frei. Sturluson podkreślał jej inne cechy, nazywając piękna kobieta, skłonna słuchać ludzkich próśb, lubiąca pieśni miłosne i ta, której pomocy należy wzywać w sprawach miłości. Nie przypadkiem zatem nazywał Freję Boginia miłości. Była więc Freja patronką miłości, chociaż - jak zauważył Słupecki - to imię bogini Frigg oznacza „ukochana”"11.

Dlaczego to zatem Freja uznawana była za boginię miłości? Jak pisał Leszek Słupecki, była ona skłonna do rozwiąłości i afer erotycznych, przy których drobne skandale zwiazane $z$ Frigg i innymi skandynawskimi boginiami nie sa nawet godne wzmianki ${ }^{12}$. Skandynawskie źródła pełne są określeń, które charakteryzuja tę stronę natury Frei, a najłagodniejsze $z$ nich to "suka”. Ziemskim kochankiem Frei był król Ottar. Chociaż to związek $z$ własnym bratem został ukazany przez Lokiego jako dowód szczególnej rozwiązłości. Wszystko, co można powiedzieć o miłosnych podbojach Frei, nie prowadzi jednak do wniosku, że była boginia płodności. Co prawda wzywano ja razem z Frigg przy połogu, a nadawane jej przydomki wskazują na podobieństwo do bogin dających radość życia seksualnego i obdarzających płodnością. W wyraźnie zarysowanym w źródłach charakterze Frei brak jednak rysów bogini płodności, widać natomiast jej mocne związki z wojna, miłością i klejnotami.

Freja praktycznie nigdzie nie jest przedstawiana jako matka, choć przypisywano jej córki zrodzone z Oda. Według Sturlusona miała jedna córkę o imieniu Hnoss. W innym miejscu ten sam autor przypisywał jej także druga córkę Gersemi. Ważnym elementem tego wątku jest pojawienie się imion córek Frei w opisie kosztowności w strofach dwunastowiecznego skalda Einara Skulasona. Imiona te oznaczaja klejnoty, można je zatem uznać za personifikację biżuterii Frei. $Z$ tym wątkiem łącza się też łzy Frei, którymi płakała, poszukując zaginionego w jej mniemaniu Oda. Łzy te zamieniały się w czerwone złoto. Całości obrazu Frei jako bogini mającej zwiazek $z$ klejnotami dopełnia jej kolejny przydomek „kobiety cieszącej się naszyjnikiem”. Najważniejszym atrybutem Frei jest Brisingamen, klejnot uznawany na ogół za naszyjnik, na pewno ozdobiony jakimś świecacym kamieniem szlachetnym, prawdopodobnie rubinem. To $z$ kolei wiążę się $z$ jej przydomkiem „zorzy świecącej nad

11 G. Dumézil, op. cit., s. 141; L.P. Słupecki, op. cit., s. 270.

12 L.P. Słupecki, op. cit., s. 270. 
morzem" oznaczającym, że Freja świeciła nad wodami blaskiem swojego klejnotu ${ }^{13}$.

Wspomniałem już wcześniej o znajomości przez Freję sztuki seidr, co czyniło z niej także wieszczkę. Znała się też na nekromancji. Gdy Freja znalazła się wśród Asów, wyznaczono jej funkcję kapłanki. Sama modliła się do Odyna i składała ofiary dla Thora. Również jej składano ofiary $z$ bydła na kamiennych ołtarzach, co miało zapewnić obfitość plonów ${ }^{14}$.

Freja miała wiele cech czyniących $z$ niej najważniejszą kobieca postać skandynawskiego panteonu. Była panią wojny, śmierci, rozwiazła opiekunką miłości lubująca się w klejnotach i złocie, opiekunką władców i biegła w czarach kapłanka. Była połączeniem znanych nam skandynawskich czy germańskich bogin.

$Z$ kolei Iduun dysponowała środkami pozwalającymi zachować wieczną młodość. Na funkcję tej bogini do pewnego stopnia może wskazywać jej imię, które w staroislandzkim oznacza „odnawiającą". Tak działały złote jabłka, których była szafarka. Spełniały swoja funkcję, odnawiając życie bogów i zachowując ich w wiecznej młodości. Działały tak jedynie wtedy, gdy oddawała je $z$ własnej woli. Poza mitem mówiącym o złotych jabłkach wiecznej młodości Iduun pojawia się jeszcze tylko w dwóch strofach Lokasenny, gdzie powstrzymuje swego męża Bragiego, by w odpowiedzi na zaczepki Lokiego nie ubliżył mu i uszanował łączace ich więzy pokrewieństwa ${ }^{15}$.

Oprócz wspomnianych już powyżej bogiń warto wymienić jeszcze Sif, żonę Thora. Należała do Asynii, a mit zwiazany z jej postacia nawiazuje - podobnie jak to było z Freja - do złota. Tym razem jednak chodzi o włosy ze złota. Otóż Sif straciła włosy, najprawdopodobniej będąc w sytuacji intymnej z Lokim, który w swojej złośliwości obciał je. W zamian Czarne Elfy (Karły), zmuszone do tego, zrobiły jej ze złota takie włosy, które rosły jak prawdziwe. Złote włosy Sif sa paralela do rudych włosów Thora, najcenniejsze bowiem złoto, a tylko takie mogło się znaleźć na głowie bogini, zwano zawsze czerwonym. Mit o złotych włosach Sif mówi o pochodzeniu najważniejszych atrybutów bogów, jest zatem jednym $z$ najistotniejszych mitów. Ponadto zbliża Sif do Frei, której związki

${ }_{13}$ G. Dumézil, op. cit., s. 142; L.P. Słupecki, op. cit., s. 271, 273.

14 L.P. Słupecki, op. cit., s. 275-276.

15 A. Bartnik, Nehalennia. Bogini z jabłkami 84 lata później. Zarys problemu, „Klio” 2012, t. 20, nr 1, s. 53; L.P. Słupecki, op. cit., s. 262. 
ze złotem były oczywiste, oraz wskazuje, że podobnie jak Freja Sif była uważana za najpiękniejszą $z$ bogiń ${ }^{16}$.

Spośród grup bogiń skandynawskich wyraźnie odrębne od męskiej części panteonu były Disy, boginie związane ze sfera płodności i śmierci. Te żeńskie bóstwa opiekuńcze przynosiły człowiekowi szczęście już w momencie porodu, a od ich łaski zależało dalsze życiowe powodzenie jednostki. Ich gniew przynosił niepowodzenia lub śmierć. Słowo „disa” było poetyckim synonimem kobiety i w strofach skaldów takie miano było zaszczytnym określeniem każdej szlachetnie urodzonej kobiety i bogini. Disom na przełomie jesieni i zimy składano ofiary ${ }^{17}$. Podobna do nich rolę spełniały Fylgie.

Norny stały ponad porządkiem tego świata. Pojawiały się w chwili narodzin człowieka. Były to trzy siostry: Urdhr, Werdhandi i Skuld - boginie decydujące o losie Bogów i ludzi. Przędly one „nici losu”. Śmierć człowieka następowała, gdy Urdhr przecinała przypisana mu nić. Od wyroku Norn nie było odwołania. Dopiero w chwili śmierci człowiek poznawał swoje przeznaczenie, o którym zdecydowano już w momencie narodzenia. Norny interweniowały w życie człowieka wtedy, gdy zagrożony był ich plan dotyczacy losów konkretnej jednostki. W Skandynawii w ich moc wierzono jeszcze długo po przyjęciu chrześcijaństwa ${ }^{18}$.

Walkirie pełniły istotna rolę w boskich zaświatach. Nazywano je „wybierajace poległych”. Były zbrojnymi wysłanniczkami Odyna i zajmowały się wykonywaniem jego wyroków - zabierały $z$ pola walki poległych wojowników, czasami same wybierały, kto zginie i wtedy sprowadzały zabitych do Wallhali. Niekiedy zdarzało się, iż Walkirie odwiedzały bohaterów za życia, oznajmiając im, do jakich heroicznych celów sa przeznaczeni. Dawały im wybór - długie i spokojne życie bez znaczenia lub pełne chwały, lecz krótkie, godne opowiedzenia następnym pokoleniom ${ }^{19}$.

Hinduizm jest religią w której ogromną rolę odgrywają bóstwa kobiece. W przeciwieństwie do religii germańskiej hinduizm jest wciąż żywy i się zmienia, co dotyczy również funkcji i roli bóstw żeńskich. Tradycja

\footnotetext{
16 L.P. Słupecki, op. cit., s. 279-280.

17 K. Kiszka, Bezpieczeństwo zapisane w słowach powieści, „De Securitate et Defensione.

O Bezpieczeństwie i Obronności" 2015, nr 1, s. 80; L.P. Słupecki, op. cit., s. 233-235.

18 K. Kiszka, op. cit., s. 80; L.P. Słupecki, op. cit., s. 238-239.

19 A. Szrejter, Mitologia germańska. Opowieści o bogach mroźnej Północy, Gdańsk 2006, s. 269; J. Puchalska, Umierać z bronia w ręku. Zaświaty dzielnych wojów Pótnocy, „Maska. Magazyn antropologiczno-społeczno-kulturowy" 2011, nr 11, s. 114-115; L.P. Słupecki, op. cit., s. 239.
} 
Wielkiej Bogini jest w hinduizmie nie mniej ważna niż tradycje Wisznu i Śiwy. Niezliczone bóstwa żeńskie w tradycjach lokalnych sa zazwyczaj przez Hindusów uznawane za personifikacje czy aspekty jedynej Wielkiej Bogini, której kult sięga najprawdopodobniej czasów prehistorycznych.

Bogini stanowi w hinduizmie postać pełną sprzeczności. $Z$ jednej strony jest źródłem życia, dobroczynną matka, obdarzająca i płodna, $z$ drugiej jednak stanowi straszliwa, złowroga siłę domagająca się ofiar, mięsa i alkoholu w celu ugaszenia gniewu. Wendy O'Flaherty wymienia odrębne kategorie bogin indyjskich, odzwierciedlające te dwie natury: Boginie zębów, które sa pełne erotyzmu, okrutne i niebezpieczne, oraz Boginie piersi - łaskawe, hojne i płodne. Te drugie stanowia zasadniczy wzorzec ról społecznych kobiet hinduskich, które mają wcielać w życie cechy macierzyńskie, matczyne, takie jak hojność, łaskawość oraz być posłuszne swoim mężom. Boginie zębów są natomiast niezależne, zajmuja niska pozycje w hierarchii i dominuja nad swoimi partnerami, o ile ich maja. Pochodzace $z$ wyższych warstw społecznych Boginie piersi pod względem seksualności pozostaja pod kontrola ideologii bramińskiej, natomiast nisko umieszczone w hierarchii Boginie zębów są wolne i atakuja mężczyzn ${ }^{20}$. W tym podziale zdarzają się jednak wyjątki, istnieja takie boginie, które są jednocześnie piękne i niezależne. Wielka Bogini Dewi łączy w sobie dwa wizerunki, a jej kulty sa odbiciem wspomnianych powyżej sprzeczności²1.

Kult Wielkiej Bogini łączy się zwykle z praktykami określanymi mianem siaktycznych lub tantrycznych. Siakti (moc) jest personifikacja energii boga w postaci żeńskiej. Byłoby jednak wielkim błędem sądzić, że tylko siaktowie czczą Wielka Boginię (małżonkę Śiwy). Jej kult ma wielu zwolenników; niemal wszyscy Hindusi czczą ją w jakimś stopniu, zwłaszcza w społecznościach wiejskich, gdzie jej wymagania i dobrodziejstwa sa zrozumiałe. Gdy mowa o wymaganiach (często budzących grozę), bogini występuje pod imionami Gauri, Uma, Parwati, w przypadku dobrodziejstw przyjmuje imiona - Durga, Kali, Ćamunda. Należy dodać, że zarówno wisznuizm, jak i śiwaizm włączyły Wielką Boginię do swoich tradycji jako partnerki czy energie bóstw męskich ${ }^{22}$. Wiąże to kult Bogini

\footnotetext{
20 W. O'Flaherty, Women, Androgynes, and Other Mythical Beasts, Chicago-London 1980, p. 91.

${ }^{21}$ G. Food, Hinduizm. Wprowadzenie, tłum. M. Ruchel, Kraków 2008, s. 183-184.

22 Ibidem, s. 184.
} 
z praktykami tantrycznymi. Tantryzm (tantra - osnowa, system nauki i ceremonii, także pisma traktujące o systemie) jest nie tyle religia czy filozofia, ile metodą prowadząca do utożsamienia się z najwyższym bytem (transcendentnym bóstwem i kosmosem) przez doskonalenie samego siebie. Tantryzm ma liczne odmiany, oprócz hinduistycznej także buddyjską i dżinijska. W tantryzmie za pomoca odpowiednich praktyk i rytuałów doskonali się ducha i ciało, które oczyszcza się np. poprzez praktykę jogi wpływającej również na umysł. Ważna jest też medytacja, której towarzyszy wypowiadanie świętych zgłosek manifestujących bóstwa (mantra). Na ogół jest to om (aum), których znaczenie ma wiele objaśnień. W jednym $z$ nich $a$ jest symbolem Siwy, $u$ uosabia siakti, $m$ symbolizuje wszelkie stworzenie. Według wyznawców mantra kondensuje w sobie energię lub moc bożą, poprawne zaś jej wypowiedzenie wzbudza specyficzną siłę pozwalająca praktykującemu na osiagnięcie identyfikacji z bogiem ${ }^{23}$.

W hinduizmie wszystkie boginie sa tylko jakimś aspektem jednej Devi, działającej w różny sposób, zależnie od konkretnej sytuacji. Najważniejsze $z$ nich to wymienione już boginie Durga i Kali.

Durga, nazywana „Niedostępna”, jest dziewica, co oznacza, że jest sama dla siebie, że nie należy do żadnego mężczyzny. Mówiąc dzisiejszym językiem, obraz Durgi pozwala zachować kobiecie własne wyobrażenie o sobie samej poza rola, jaka przydzieliło jej patriarchalne społeczeństwo. A im bardziej ogranicza się jej wolność, tym bardziej „waleczne dziewictwo" jest dla niej obrona.

Durga to aspekt Boskiej Matki, ale pod postacia żeńskiej siły stwórczej. Wszystkie późniejsze hinduskie boginie sa emanacją bogini Durgi, która powstała $z$ niemocy bogów, wyczerpanych długotrwała walka przeciwko demonom. Ich energia połączyła się w świetlistą kulę miotająca ogniste płomienie we wszystkich kierunkach. Światłość przeniknęła trzy światy, skupiła się i przybrała postać kobiecą. Bogini o trzech oczach i wielu ramionach (najczęściej ośmiu), $z$ sierpem księżyca we włosach, dosiadająca tygrysa (lub lwa) pokonuje całą armię asiurów, używając męskiego oręża - miecza, topora, kija, lancy, trójzębu i innych, a ich przywódcę niszczy święta zgłoską om. W dłoniach trzyma też girlandę kwiatów, naszyjnik pereł, konchę, kwiat lotosu i inne symboliczne znaki.

${ }_{23}$ W. Wilowski, Hinduizm, „Wiedza i Życie” 1996, nr 1, [online], [Dostęp: 30.10.2017]. Dostępny w World Wide Web: <http://bit.ly/2z8BNT9>. 
Jest jedna $z$ najwspanialszych i najbogatszych $\mathrm{w}$ znaczenie personifikacji energii kosmicznej. Toczona przez Durge walka to odwieczne starcie między wiedzą i niewiedza, prawdą i nieprawda, boskim szlachetnym czynem utrzymujacym świat $\mathrm{w}$ harmonii a niszczącym świat ego asiurów. Pokonuje ostatniego najsilniejszego demona Mahisasurę, który atakuje pod postacią byka. Durga musi również odeprzeć ataki męskiego uroku, którym asiurowie pragna ją usidlić i wytrącić broń $z$ ręki - zachowuje kobieca godność i moc samostanowienia.

Kali wydobyła się ze zmarszczonego gniewem czoła Durgi i na jej rozkaz pożarła resztki armii demonów, odcinając głowy Ciandy i Mundy. Dlatego w niektórych regionach Indii południowych bogini Durga i sprzymierzona $z$ nią bogini Kali nazywane są Ćamundą.

Moc Durgi nie pochodzi w żadnej mierze ze zwiąku $z$ bogiem-małżonkiem, lecz z własnej, samodzielnej, całkowicie ukształtowanej tożsamości. Indyjskie boginie maja zdolność samodzielnego kształtowania losów świata, zwyciężając siły zła wtedy, gdy bogowie są słabi lub nie znajduja pomysłu na rozwiązanie konfliktu. Wiele modlitw i inkantacji skierowanych jest właśnie do Durgi i nawet bogowie błagają ją o wstawiennictwo w przegranych sprawach.

Według wierzeń indyjskich w świecie stale działają dwie równoważne siły - asiurowie, demony i dewowie, bogowie. Ani jedni, ani drudzy nie sa wystarczająco mocni, by przeciagnać świat na swoją stronę. $Z$ wściekłości bogów i ich niemocy pokonania asiurów zrodziła się bogini Durga. W sytuacji zablokowania dwóch równoważnych sił - zła i dobra tylko moc żeńska jest zdolna wprowadzić nowy element oraz ustanowić nowy pokój i równowagę. Bogowie oddali Durdze swą męską moc pod postacią ognistych płomieni.

Kali jest symbolem Boga w aspekcie wiecznej Matki Przyrody, bezlitosnej w swych prawach, to znaczy doskonale emocjonalnie obojętnej wobec ludzkiej psyche. Uosabia wieczny pierwiastek żeński w przyrodzie. Postać Kali pojawiła się w źródłach przedaryjskich i pochodzi z najstarszej warstwy wierzeń indyjskich, podobnie jak Durga, Śiwa czy Kriszna. W piśmiennictwie znana jest od około 400 r. p.n.e., symbolizując walke wprost. Jako najbardziej wojowniczy aspekt Durgi pojawiła się, by unieszkodliwić męskie moce demoniczne i wprowadzić w świecie nowa równowagę.

Kali nie zawsze jest okrutna i mściwa, bywa też łaskawa. Tradycyjnie przedstawia się ją jako czarną kobietę stojącą na postaci boga 
Śiwy, Nieskończonego. Kolor czarny oznacza absolutna pierwotność i tak jak wszystkie kolory znikaja w czerni, tak wszystkie boskie imiona i formy rozmywaja się w jednej postaci - Kali. Jest czystą natura, prakriti, bez żadnych przymiotów. W swej pierwotnej, absolutnej nagości nie osłania jej żadna ozdoba, iluzja. Rodzi świat w akcie partenogenezy, gdyż nosi w sobie pierwiastek męski. Zmierzwione włosy tkają zasłonę iluzji, siatkę czasoprzestrzeni, która wydobywa materię z chaosu. Naszyjnik z ludzkich czaszek symbolizuje pięćdziesiąt liter sanskryckiego alfabetu, każda jest zaczątkiem wiedzy i mądrości. U jej pasa zwisają ludzkie ręce - podstawowe narzędzie pracy oznaczające działanie karmy i ciężar nagromadzonych czynów. Troje oczu oznaczaja przeszłość, teraźniejszość i przyszłość, białe zęby sattwę, świetlistość i lekkość umysłu, zaś zwisający czerwony język - radżas, energię sprawczą wyczerpująca się aż do inercji bezwładu, tamas. Kali ma najczęściej cztery ramiona, niekiedy tylko dwa, często sześć lub nawet osiem (jak Durga); w ręce lewej trzyma odcięta głowę oznaczajaca pokonanie zła uczynionego przez destrukcyjną siłę ego, w drugiej - naczynie $z$ ogniem duchowym. Ręką prawą czyni gest uśmierzajacy strach, a w drugiej dzierży miecz przecinający więzy zniewolenia. Nie depcze leżącego Śiwy, lecz przywołuje go do istnienia i pobudza do życia.

Kult Kali to całkowite oddanie siebie pod kuratelę boskiej matki, aż do zatracenia osoby, osobowości, własnego Ja i ostateczne stopienie się jaźni $z$ archetypem. Poprzez mistyczny zwiazek $z$ boginią odnajduje się własne zagubione, prawdziwe Ja, które jest esencją świata.

Niekiedy Kali przybiera kolor biały, symbolizując dziewicę i stworzycielkę, czerwony - jako Matka żywicielka oraz czarny - jako ta, do której wszystko zmierza, by ostatecznie zamrzeć. Uosabia cykliczność stworzenia, otwarcia i zamknięcia, życia i śmierci. Jest ta, która życie daje i je zabiera. Kali przebywa w miejscach kremacji - przyjmuje w swe ramiona każdą umarła osobę. Jej dotyk - śmierć - wyzwala od ciężaru życia, uśmierza ból i cierpienie, koi niepokój, przemienia, przynosząc spokój i wolność.

Kali to archetyp jogini i wszystkie teksty tantryczne opiewajace kobietę-wyrzeczeńca poprzez jej postać wielbia nieograniczoną żeńskość, przypominając, że czas i przestrzeń przynależą do materii, którą wcześniej czy później należy pokonać. Tak długo, jak pozostajemy w niewoli czasu i przestrzeni, tak długo nie uzyskamy wolności. Kali to moc działania iluzji czasu - pojąć to i przekroczyć czas, to uzyskać wolność. 
W doktrynach śiwaickich każda dusza jest żeńska, a mężczyzna idealny dąży do rozwijania w sobie cech kobiecych. Pełnia człowieczeństwa to pełnia męskości i kobiecości. Dlatego w Indiach zachęca się mężczyzn do wypracowania w sobie cech uważanych potocznie za kobiece - łagodność, brak agresji, akceptacja życia jako takiego we wszystkich jego odmianach i niuansach, brak oceniania i krytycyzmu oraz "matkowanie" światu. Mężczyzna nie jest inicjowany do roli wojownika, lecz do roli obrońcy.

Kult bogini Kali przetrwał w najsilniejszej formie w Bengalu, gdzie każda wioska ma swoja kalibari, przybytek bogini. Jej wielkim poddanym był Ramakrishna, mistyk bengalski z XIX w., który przywrócił w Indiach jej czysty kult. Światynia Dakshineswar w północnej Kalkucie stała się najważniejszym miejscem kultu. Kolonizujący w tym czasie Kalkutę Anglicy myśleli, iż owa intensywność oddawania kultu bogini jest typowa dla całych Indii - miasto było zbudowane na ziemi Kali (Kali-kshetra), nad brzegiem Gangi i nazywało się Kalighat. Ale to Ramakrishna i jego uczeń Wiwekananda swym żarem oddania przyciagnęli innych mieszkańców nowego miasta. W walce o niepodległość Indii Kali zyskała nowa symbolikę - jako personifikacja Bengalu pomogła wystapić w ataku frontalnym przeciw Anglikom, a walka ta rozpoczęła się właśnie w Kalkucie ${ }^{24}$.

W hinduizmie popularne sa też zwiąki par Bogów, które maja być przykładami idealnych związków pomiędzy kobietą a mężczyzną. Już w sferze mitologicznej zarysowane sa pewne idealne typy takich relacji. Niewatpliwie należy do nich zwiazek Ramy i Sity, Kriszny i Radhy, Siwy i Parwati czy Wisznu i Lakszmi. Omówię tylko część tych mitologicznych zwiąków.

O zwiąku Ramy i Sity dowiadujemy się z eposu Ramayana. Przygody króla Ramy (wcielenie Wisznu) i jego małżonki Sity dostarczają idealnego wzorca króla i męża oraz żony, prezentuja idealny typ związku małżeńskiego. W eposie wyrażona jest idea, w myśl której obowiązkiem każdej żony jest wierne towarzyszenie małżonkowi, nawet w sytuacjach krytycznych, jaką niewątpliwie było wygnanie księcia Ramy:

Z uśmiechem na twarzy będę kroczyć przed tobą leśnymi ścieżkami, depcząc kolce i ciernie, by wymościć drogę dla twych stóp. U twego

24 Devi, Durga, Kali i inne boginie, [Dostęp: 02.11.2017]. Dostępny w World Wide Web: <http://bit.ly/2Nq296c>. 
boku nawet w głuchym lesie będę szczęśliwa jak w pałacu ojca, służąc ci wiernie i nie dopuszczając myśli o wspaniałościach całego Trójświa$\mathrm{ta}^{25}$.

Sita ukazana jest tu przede wszystkim jako wierna żona, co wyeksponowane jest szczególnie poprzez wątek $z$ nieustępliwym w zalotach i próbach uwiedzenia jej demonem Rawaną:

Chodź ze mna, kobieto o czułym spojrzeniu, nie opieraj mi się więcej! Smakujmy razem rozkosze życia! Po co ten ból? To chyba rzecz naturalna przyłączyć się do zwycięstwa? To ja jestem zwycięzca! Po cóż te wahania? Lecz Sita nie widziała go, nie słyszała, jęczała pod ciężarem nieszczęścia, którym los ją przytłoczy ${ }^{26}$.

Reakcja Sity na umizgi demona była zawsze stanowcza odmowa, wypływająca niewatpliwie $z$ ogromnej miłości i oddania małżonkowi. W wyniku podejrzliwości, co do prowadzenia się Sity podczas porwania, Rama powzią postanowienie porzucenia swej żony. Ta $z$ rozpaczy rzuciła się na płonacy stos, lecz Agni nie chciał jej przyjać. Nawet próba ogniowa nie była w stanie uśmierzyć podejrzenia ludu, co do czystości Sity. W obliczu zaistniałej sytuacji Rama, mimo głębokiego przekonania o nieskalaniu małżonki, skazał ją na wygnanie. Dopiero po kilu latach rozłąki odnalazł ją wraz $z$ narodzonymi w tym czasie dziećmi. W odpowiedzi na to Sita, aby dać ostateczny dowód swojej miłości, poprosiła Ziemię, aby ta ją wchłonęła ${ }^{27}$.

Nieco odmienne relacje ukazane sa na przykładzie boskiej pary Radhy i Kriszny. Akcent przeniesiony jest tutaj na namiętność. Atmosfera, jaka panuje wokół boskich kochanków, nasycona jest erotyzmem, pasją i spontanicznością.

W XVIII w. między wisznuitami doszło do debaty na temat czy Radha była żona, czy kochanką boga. W następstwie owej dyskusji uznano wyższość Radhy jako kochanki, ponieważ jej miłość stanowiła dobrowolny dar serca i namiętności. Była gotowa poświęcić Krisznie całe swoje życie. Ideał prezentowany przez zwiazek Radhy i Kriszny nie był

25 Ramayana, adapt. E. Walterowa, Warszawa 1993, s. 64.

${ }^{26}$ Cyt. za: F. Comte, Najsłynniejsze święte księgi świata. Leksykon, przeł. E. Bekier, Łódź 1994, s. 102.

27 I. Wojtarowicz, Kobieta w hinduizmie, [online], [Dostęp: 02.11.2017]. Dostępny w World Wide Web: <http://bit.ly/2u1gjTh>. 
akceptowalny przez całe społeczeństwo, aczkolwiek sukcesywnie wcielał się w życie społeczne, nabierając coraz większego znaczenia: Kochanka może dasać się, gniewać i robić wymówki ukochanemu, czego nie wolno czynić oddanej żonie, ta musi znosić wszystko cierpliwie.

Kriszna i Radha sa nierozłączna całościa, razem stanowia Absolut. W tym Absolucie Kriszna określa zasadę męska, pierwiastkiem żeńskim pojawiającym się jako twórcza moc boga jest zaś Radha. Miłość tej boskiej pary jest symbolem związku między duszą człowieka a bogiem. Gdy są od siebie oddzielone, tęsknią za połączeniem - tak jak było w przypadku Radhy i Kriszny. Wyznawcy wierza w ideę „Boskiej igraszki”, która stanowi dla nich zasadę wszechświata ${ }^{28}$.

Omawiane tutaj bóstwa żeńskie zarówno w przypadku religii skandynawskiej, jak i hinduizmu odwołują się do archetypu kobiecości. Związany jest on $z$ płodnością i narodzinami, śmiertelnością (a także eschatologia), ale też seksualnością. Mówi, jak się stać kobietą „kompletna”. Te elementy obserwujemy tak w postaci bogini Frei, jak i hinduskiej Durgi czy Kali. Należy jednak pamiętać, że nie zawsze legalne związki boskich par sa stymulujące dla ich męskich części. To kobieta pobudza w mężczyźnie nowy sposób widzenia rzeczywistości i dostarcza mu namiętności, inspiracji oraz chęci życia. I chociaż mowa tu o wzorach, jakich dostarczały boginie i boskie pary, to niewatpliwie wzory te były przykładem postępowania i czerpania idei dla zwykłych ludzi.

\section{Bibliografia}

\section{Źródła}

Comte Fernand, Najsłynniejsze święte księgi świata. Leksykon, przeł. Ewa Bekier, Łódź : Wydawnictwo OPUS, 1994, ISBN 83-7089-023-7.

Edda poetycka, ze staroislandzkiego przeł. i oprac. Apolonia Załuska-Strömberg, Wrocław : Zakład Narodowy im. Ossolińskich, 1986, ISBN 83-0402222-2.

Ramayana, adapt. Elżbieta Walterowa, Warszawa : Wydawnictwo Alfa, 1993, ISBN 83-7001-649-9.

Szrejter Artur, Mitologia germańska. Opowieści o bogach mroźnej Pótnocy, Gdańsk : Wydawnictwo L\&L, 2006, ISBN 83-88595-99-7.

28 Ibidem. 


\section{Opracowania}

Bartnik Agnieszka, Nehalennia. Bogini z jabłkami 84 lata później. Zarys problemu, „Klio” 2012, t. 20, nr 1, DOI: http://dx.doi.org/10.12775/ KLIO.2012.002.

Devi, Durga, Kali i inne boginie, [Dostęp: 02.11.2017]. Dostępny w World Wide Web: <http://bit.ly/2Nq296c>.

Dumézil Georges, Bogowie Germanów. Szkice o kształtowaniu się religii skandynawskiej, przeł. Anna Gronowska, Warszawa : Oficyna Naukowa, 2006, ISBN 83-7459-014-9.

Food Gavin, Hinduizm. Wprowadzenie, przeł. Małgorzata Ruchel, Kraków : Wydawnictwo Uniwersytetu Jagiellońskiego, 2008, ISBN 978-83-2332517-8.

Kiszka Krystian, Bezpieczeństwo zapisane w słowach powieści, „De Securitate et Defensione. O Bezpieczeństwie i Obronności” 2015, nr 1, s. 72-88, ISSN 2450-5005.

Niemczyk Wiktor, Historia religii, z rękopisu wydali, oprac. i uzup. Jan B. Niemczyk, Janusz T. Maciuszko, wyd. 2, Warszawa : Chrześcijańska Akademia Teologiczna, 1986.

O'Flaherty Wendy, Women, Androgynes, and Other Mythical Beasts, Chicago-London : University of Chicago Press, 1980, ISBN 0226618498.

Piekarczyk Stanisław, Mitologia germańska, Warszawa : Wydawnictwa Artystyczne i Filmowe, 1979, ISBN 83-221-0076-0.

Puchalska Joanna, Umierać z bronia w ręku. Zaświaty dzielnych wojów Pótnocy, „Maska. Magazyn antropologiczno-społeczno-kulturowy” 2011, nr 11, s. 107-122, ISSN 1898-5947.

Słupecki Leszek Paweł, Mitologia skandynawska w epoce Wikingów, Kraków : Zakład Wydawniczy Nomos, 2014, ISBN 978-83-88508-55-4.

Wojtarowicz Ilona, Kobieta w hinduizmie, [online], [Dostęp: 30.10.2017]. Dostępny w World Wide Web: <http:/ / bit.ly/2u1gjTh>.

Wilowski Włodzimierz, Hinduizm, „Wiedza i Życie” 1996, nr 1, [online], [Dostęp: 30.10.2017]. Dostępny w World Wide Web: <http://bit. ly/2z8BNT9>. 